\title{
Malignant proliferating trichilemmal tumour: a case report
}

\begin{abstract}
Proliferating trichilemmal tumour (PTT) is an uncommon neoplasm that has been derived from the outer root sheath of hair follicle. We describe a case of a 73year old female who presented with solitary friable nodular mass on scalp measuring $3.5 \times 2 \times 1 \mathrm{~cm}$. She underwent local excision of this growth. Histologically, tumour shows trichilemmal keratinisation without interposed granular layer which was characterized by poor circumscription with invasion of surrounding tissue with marked nuclear atypia, hyperchromasia and atypical mitotic activity.
\end{abstract}

Volume 2 Issue 2 - 2016

\author{
Rachana Dhakal \\ Department of Pathology, Kathmandu University School of \\ Medical Sciences, Nepal
}

Correspondence: Rachana Dhakal, Department of Pathology, Kathmandu University School of Medical Sciences, Nepal,Tel 9779841777944,Email sigdelrachana@gmail.com

\section{Introduction}

Proliferating trichilemmal tumour (PTT) is a rare skin neoplasm. It was first described as "proliferating epidermoid cyst" by Wilson and Jones in $1966 .{ }^{1}$ These lesions are the cutaneous neoplasms that are derieved from the outer root sheath of the hair follicles. ${ }^{2}$ PTT present as solitary nodules on scalp in elderly women. In rare instances, malignant transformation of proliferating trichilemmal cyst takes place. ${ }^{3-5}$ This is indicated clinically by rapid enlargement of the nodule. Histopathologically, tumour shows trichilemmal keratinisation without interposed granular layer, invasion associated with nuclear atypia, giant cell nuclei and tumour necrosis that indicate malignancy which is described as malignant proliferating trichilemmal tumour (MPTT) ${ }^{6}$

\section{Case report}

A 73year old male presented to the hospital with a solitary friable nodular mass on scalp measuring $3.5 \times 2 \times 1 \mathrm{~cm}$. She underwent local excision of this growth. Grossly, specimen consists of single piece of partly skin covered friable nodular mass $3.5 \times 2 \times 1 \mathrm{~cm}$. Histologically, tumour shows trichilemmal keratinisation without interposed granular layer which was characterized by poor circumscription with invasion of surrounding tissue with marked nuclear atypia, hyperchromasia and atypical mitotic activity (Figure $1 \&$ Figure 2).

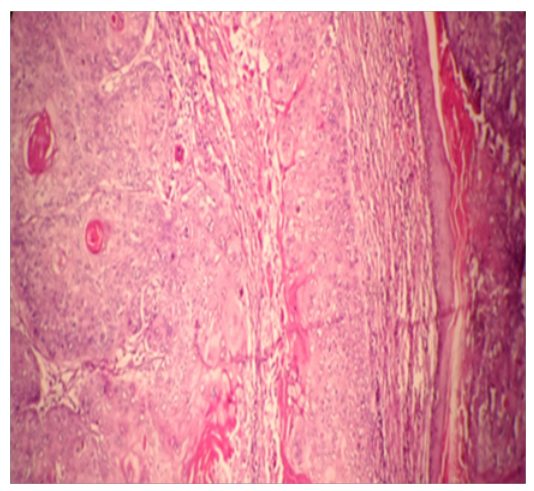

Figure I Tumour islands of pleomorphic squamous cells with keratin pearls in dermis (X40).
Received: February 22, 2016 | Published: February 26, 2016 
in diameter and shows cytological atypia and mitotic activity. ${ }^{18}$ The treatment of choice is surgical resection. However, due to high local recurrence rate, Mohs micrographic surgery would be a therapeutic option..$^{19}$

\section{Conclusion}

MPTT appears as diagnostic dilemma for the surgeon as well to the pathologists. It is crucial to distinguish MPTT from SCC due to similar morphological characteristic which may affect the treatment approach for the patient. Hence, immunohistochemistry is useful in differential diagnosis and determining morphological characteristics.

\section{Acknowledgements}

None.

\section{Conflict of interest}

The author declares no conflict of interest.

\section{References}

1. Jones EW. Proliferating epidermoid cysts. Arch Dermatol. 1996;94(1):1119.

2. Chaichamnan K, Satyasoontorn K,Puttanupaab S, et al. Malignant proliferating trichilemmal tumours with CD34 expression. J Med Assoc of Thai. 2010;93(Suppl 6):S28-34.

3. Brownstein MH, Arluk DJ. Proliferating trichilemmal cyst: a stimulant of squamous cell carcinoma. Cancer. 1981;48(5):1207-1214.

4. Satyaprakash AK, Sheena DJ, Sangueza OP. Proliferating trichilemmal tumours: a review of the literature. Dermatol Surg. 2007;33(9):1102-1108.

5. Matte SMW, Melo IS, Pinto MS, et al. Cisto triquilemal proliferante:relato de um caso exuberante. An Bras Dermatol. 1997;72:206-210.

6. Amaral AL, Nascimento AG, Goellner JR. Proliferating pilar (trichilemmal) cyst. Report of two cases, one with carcinomatous transformation and one with distant metastasis. Arch Pathol Lab Med. 1984;108(10):808-810.

7. Yamaguchi J, Irimajiri T, Ohara K. Proliferating trichilemmal cyst arising in the arm of a young woman. Dermatolog. 1994;189(1):90-92.
8. Karaca S, Kulac M, Dilek FH, et al. Giant Proliferating trichilemmal tumours of the gluteal region. Dermatol Surg. 2005;31(12):1734-1736.

9. Leppard BJ, Sanderson KV. The natural history of trichilemmal cysts. $\mathrm{Br} J$ Dermatol. 1976;94(4):379-390.

10. Rutty GN, Richman PI, Laing JH. Malignant change in trichilemmal cysts: a study of cell proliferation and DNA content. Histopathology. 1992;21(5):465-468

11. Sau P, Graham JH, Helwig EB. Proliferating epithelial cysts: clinicopathological analysis of 96 cases. J Cutan Pathol. 1995;22(5):394406.

12. Folpe AL, Reisenauer AK, Mentzel T, et al. Proliferating trichilemmal tumours: clinicopathological evaluation is a guide to biologic behavior. $J$ Cutan Pathol. 2003;30(8):492-498.

13. Hayashi I, Harada T, Muraoka M, et al. Malignant proliferating trichilemmal tumour and $\mathrm{CAV}$ (cisplatin, adriamycin, vindesine)treatment. Br J Dermatol. 2004;150(1):156-157.

14. Lopez-Rios F, Rodriguez-Peralto JL, Aguilar A, et al. Proliferating trichilemmal cyst with focal invasion: report of a case and a review of literature. Am J Dermatopathol. 2000;22:183-187.

15. Tierney E, Ochoa M, Rudkin G, et al. Mohs' micrographic surgery of a proliferating trichilemmal tumour in a young man. Dermatol Surg. 2005;31(3):359-363.

16. Gulati HK, Deshmukh SD, Anand M, et al. Low-grade malignant proliferating pilar tumor simulating a squamous-cell carcinoma in an elderly female: a case report and immunohistochemical study. Int $J$ Trichology. 2011;3(2):98-101.

17. Rangel-Gamboa L, Reyes-Castro M, Dominguez-Cherit J, et al Proliferating trichilemmal cyst: the value of ki67 immunostaining. Int $J$ Trichology. 2013;5(3):115-117.

18. Folpe AL, Reisenauer AK, Mentzel T, et al. Proliferating trichilemmal tumors: clinicopathologic evaluation is a guide to biologic behavior. $J$ Cutan Pathol. 2003;30(8):492-428.

19. Tierney E, Onchoa MT, Rudkin G, et al. Mohs' micrographic surgery of a proliferating trichilemmal tumor in a young black man. Dermatol Surg. 2005;31(3):359-363 